International Journal of Applied Linguistics \& English Literature

ISSN 2200-3592 (Print), ISSN 2200-3452 (Online)

Vol. 1 No. 3; July 2012 [Special Issue on World Literature in English]

\title{
The Mad, Madness and Chaos in Lessing's The Sweetest Dream
}

\author{
Noor Azah C. Abdullah \\ Universiti Putra Malaysia, Malaysia \\ Rohimmi Noor \\ Universiti Putra Malaysia, Malaysia
}

Received: 10-07- 2012

Accepted: 25-07- 2012

Published: 31-07- 2012

doi:10.7575/ijalel.v.1n.3p.35

URL: http://dx.doi.org/10.7575/ijalel.v.1n.3p.35

\begin{abstract}
Set in Swinging London in the Sixties Doris Lessing's novel titled The Sweetest Dream ${ }^{1}$ presents a chaotic environment amidst the moral and psychical rubble of World War I and World War II. The Sixties is a transitional era sandwiched between the aftermath of wars and the effort to rebuild the country, full of socially and politically chaotic situations. On the social front, delinquent acts such as stealing become a common practice and initiation into groups among teenagers. Social chaos is also marked by broken families and insanity. Political chaos is marked among other things by The Revolution, meetings and street rallies. This paper looks at the portrayal of "inflated consciousness" in relation to chaos, the mad and madness in the novel using Carl Gustav Jung's analytical psychology's lens in order to understand how the psyche negotiates itself out of chaos to restore balance and order. This paper limits its discussion to the first half of the novel, focussing on "Swinging London.",2
\end{abstract}

Keywords: bohemian lifestyle, Jungian inflated consciousness, moral and psychical chaos

Introduction

In The Sweetest Dream Lessing depicts the delinquent behaviours of the characters coloured by the mad and madness displayed by three generations of the Lennoxes: Philip and Julia represent the first generation, Johnny, Frances and Phyllida represent the second generation, while Andrew and Colin and their friends represent the third generation. Julia still abides by honourable upper class values, these values are eroded to a certain degree by the aftermath of war, but it is the second and third generations (post-war children) who are badly affected by moral and psychical chaos. They are attracted to delinquent behaviour which they naively think is geared towards building a better society.

\section{Theoretical framework}

Jung believes that an inflated consciousness is always egocentric. It is conscious of nothing but its own existence and it is incapable of learning from the past, understanding contemporary events, and drawing right conclusions about the future because it is hypnotised by itself. As such it inevitably dooms itself to calamities. Inflated consciousness is a regression of consciousness into unconsciousness that occurs when consciousness takes too many unconscious contents upon itself and loses the faculty of discrimination. Things (the effects of inflated consciousness) are not so bad when everybody is in the same boat because no doubts can exist in the herd; the bigger the crowd, the greater the so-called "truth" (which is actually lies and confusion) becomes and the greater the catastrophe resulting from it. ${ }^{3}$ In other words, we could say that Jung's "inflated consciousness" is fixative in nature and it causes disorientation and confusion because the conscious is drowned in the unconscious that floods into it, causing imbalance to the psyche. As such, it causes a shocking effect, which is an effect un-noticed by the sufferer both because of "inflated consciousness" and because everybody in the crowd is suffering from it.

Although Jung sees "doom" and "calamities" in this situation, he believes that morality that is found at all levels of society could act as the instinctive regulator of actions, which also governs the collective life of the herd" Therefore, if this morality is unsound or has been shattered and reduced to chaos, for example by war, then the collective life of the herd is unchecked and great damage to the society is expected and an upheaval of forces lying dormant in the unconscious would break free from the control of the conscious. According to Jung, this upheaval is necessary, despite its negative effects, because it is actually a compensatory move. If this 
International Journal of Applied Linguistics \& English Literature

ISSN 2200-3592 (Print), ISSN 2200-3452 (Online)

Vol. 1 No. 3; July 2012 [Special Issue on World Literature in English]

compensatory move is integrated into consciousness, it could set things back into order again, but if it is not integrated into consciousness, it can lead to a neurosis or even to a psychosis.

Through his observations, Jung notices that the tide that rose in the unconscious after the first World War was reflected in individual dreams in the form of collective mythological symbols, which expressed primitivity, violence, and cruelty - in short all the powers of darkness. When a symbol occurs in a large number of individuals and is not understood, it draws these individuals together as if by magnetic force, and, thus, a mob is formed and dark forces are released causing suffering and destruction. Theoretically, Jung believes that when an individual is able to cling to a shred of reason, or to preserve the bonds of a human relationship, a new compensation would be brought about in the unconscious by the chaos of the conscious mind, and this compensation could be integrated into consciousness. When this happens, new symbols of a collective nature appear and reflect the forces of order. ${ }^{5}$

\section{Discussion}

Set in an era sandwiched by two world wars and the attempt to rise out of the chaos and ruins to build a new life, Doris Lessing's The Sweetest Dreams contains strong images of disorientation and confusion, which, in severe cases, causes madness in the characters and, in mild cases, merely flowing along with the herd without being able to discriminate between right and wrong. In the first part of the novel, morality appears to be muted and the voice of conscience is silenced by The Revolution. Dreams do not appear in the characters' sleeping state but appear in their waking state in the form of a hope and vision for a better future. This makes the image of "Paradise" their mythological symbol for the collective dream, envisioned by the second generation, such as Johnny. Thus, they make "saving the world" from the chaotic situation set by war and turning it into paradise on earth their agenda and goal (220-222). Ideal as it sounds, this struggle is marred by the disorientation and confusion in the "saviours" as represented by Johnny. Consequently, delinquent actions take the centre role, creating a world of deviance ${ }^{6}$ instead of the dreamed Paradise.

\section{Chaos, the mad, and madness}

Although the wars' physical casualties are not grotesquely portrayed in the first half of the novel, the brief description of Julia's three brothers fighting in the trenches while her father works in the war office (23) while her mother does war work (25) gives us meaningful snapshots of war on the family level. The older generation sends the younger generation into the battlefield and the latter ends up either being killed or maimed. Two of Julia's brothers die in the first war while the youngest, a teenager, survives but is crippled and sits with a stiff leg propelled before him on a stool (25). Unfortunately, survival is temporal for he is later killed in the second war (37); thus, making the end of the younger male generation that of being killed or being maimed and later killed, creating a picture of inevitable death for soldiers (males), and leaving Julia the only surviving child (female) in the family. This snapshot reveals how war injects an element of chaos and sense of loss in family life. On the social level, a great loss/death of calibre young men during the wars becomes one of the reasons why women represented by a character named Betty remain spinsters (27). The surviving ones, like Julia's husband Philip, lose one arm but are still active in office.

From a chaotic family Lessing zooms out into a larger picture. She presents a chaotic effect of war on lovers and their countries. War redefines the German/English relationship from friendly to warring countries. The seeds of love sown by Julia and Philip before the war materialise into marriage after the war-a union that houses a sad and splitting ideological twist. Julia, a German girl from the Nazi world, marries Philip, an English man from the Capitalist world. This union produces a Communist son, Johnny. There is no indication that Julia is a Nazi. She is merely portrayed as a victim of vicious rumour-mongering that spread during the war saying that she was a spy (29). Superficially, Julia and Philip lead a normal life but there is a part of Philip that is out of reach and is always there to hinder full happiness and understanding between them, a place forever barred from Julia, marred, a "reserve," a "coldness," and a "forbidden place," an area marked "VERBOTEN, No entrance" (27). Perhaps we could say that it is Philip's repressed side, an inner world that he locks away from the outer reality. If this is the case, then it indicates the existence of a certain degree of madness in him. Therefore, madness, though mildly portrayed, begins in the first generation of war itself.

In the second generation of war, the chaotic situation is observable in the lives of Johnny, Frances and Phyllida. Frances' parents disapprove of her marriage to Johnny. She is a solicitor's daughter from Kent (77). Her parents consider her an enemy and traitor for marrying a communist and becoming one herself. Even Julia disapproves of their marriage but later learns to accept Frances, takes her into the Lennox household and helps her to raise 
her children while Johnny, who is busy with his mission of saving the world, merely utters unfulfilled promises and gives all sort of excuses to avoid fulfilling his responsibilities as a father and ends up in a divorce.

Johnny's second marriage to Phyllida, who has a daughter named Sylvia by her first marriage, also fails. He dumps Phyllida, who is incapable of taking care of herself and is constantly in a crazy state: crying, screaming, fainting in coils and is rather mad, into Frances' care. Her daughter, Sylvia, an anorexic, also ends up in the Lennox household. Johnny cannot cope with Phyllida because she suffers psychological disorders and had a traumatised childhood. At the beginning of the war her family sent her off to a "wasn't very nice family" in Canada at the age of ten until she was almost fifteen. She hated it all and when she came back she was a changeling $(21,42-43,90)$, or to put it bluntly-mad. While Frances is accepted into the family, Phyllida and Sylvia are the patients/guests, Johnny himself remains a stranger in his mother's house, always in row and argument with her. When he runs out of money, he runs to his mother, whom he calls the class enemy for money. He even calls her and old bitch and a fascist bitch. The once honourable upper class Julia von Arne of German now ends up as Julia Lennox in London, surrounded by chaos, the mad and madness. In another instance, outside the Lennox household, Rupert's wife, Meriel, went in and out of the mental hospital. Her insanity seems to be caused by post-natal depression (262); however, the story behind it reveals another cause - her chaotic background and repressed past—she is the daughter of a famous communist father, Sebastian Heath, and an unnamed communist mother who committed suicide (267).

Born as Jolyon Meredith Wilhelm Lennox, Johnny is not a picture of sanity, himself. He has combative critical blue eyes that are often directed at his mother. This gives us a clue to his relationship with his mother when he grows up. The mad and madness are traceable to his childhood. He cannot accept the fact that he is a German, he dislikes his German family, the place and the different manner (27). He disappears from Eton, leaving a note signed Comrade Johnny Lennox, saying he is joining the Spanish Civil War, when, in actual fact, he is in a house in the East of London. He is sick, being taken care of by Comrade Mary, in need of money, and has never been to Spain, but in the Young Communist League, he is a star, A Spanish Civil War hero. Comrade Mary describes his sickness as "having a bit of breakdown." He returns to his family's house, occupies the whole floor, has many young communists as visitors and is always going to meetings, rallies, weekend schools and marches (29-30). In Johnny, we begin to see how the personal unconscious that enters the consciousness of a child causes disturbances. This leads him to ignore his patriotism from his parents' countries (Britain and Germany) and identifies himself with a third country/party - the communists - in his teenage years. During this time he is surrounded by massive unconsciousness in the form of ideology and delinquent behaviours that flow into his consciousness from meetings and rallies.

The contents of Johnny's unconscious are never realised and integrated into his consciousness. Consequently, he is trapped in his "inflated consciousness" and stays egocentric and dedicates himself to The Revolution, placing the struggle for The Revolution before family obligations (186). Johnny not only flows along with the herd psyche but becomes a strong force in meetings and rallies spreading the unconscious and "inflated consciousness" into his peers and the next generation through his speeches and revolution handbook. Unlike Johnny, Frances, his first wife pulls herself out of The Revolution. She comes to realise that it is a "glamour" that enchants her teenage (nineteen year-old) life (119). She sees it as pointless, "it was all for nothing" and "all lies and nonsense" just "a waste" of "effort" and people were "killed for nothing. Good people" (120). In Frances the "shred of reason" and morality that unites her conscious and unconscious and swings her out of the herd psyche come from her own observation and perception. To Frances, "The Revolution" is like directing a flame-thrower over anything, leaving scorched earth, and then he and his mate would rebuild the world in their image - an improbable dream. Furthermore, how could people unable to organise their own lives, who live in permanent disarray, build anything worthwhile (53)?

Chaos, the mad, and madness in the third generation, her sons' friends, whom Frances calls the "children of war," are manifested in their unruly lives (4), psychological problems (134) and engagement in delinquent acts (5). Accounts on their behaviour are gathered at Frances' dining table. Most of them shoplift in an impulsive way, but Geoffrey, a head-boy of St Joseph School and a son of a bomber pilot, makes a business out of shoplifting and considers himself "liberating" the things he steals. Frances and Andrew disapprove of this behaviour, but Johnny encourages it, saying that it is right to steal from the capitalists because they've stolen it from the people (49).

The ideological collision between The Revolution and Capitalism/Imperialism causes moral and psychical chaos in the third generation. It contributes to their psychically "disturbed" state and delinquent actions due to their 
International Journal of Applied Linguistics \& English Literature

ISSN 2200-3592 (Print), ISSN 2200-3452 (Online)

Vol. 1 No. 3; July 2012 [Special Issue on World Literature in English]

naive perception and confusion. Consequently they are drowned in the psyche of the crowd and become "not normal". Note how Julia views them:

These people are not normal, Frances [...] how is it that a son may talk to his mother as Colin does to you? [...] The house is full of [...] [Julia censors herself] you allow them here, they take advantage of you and they are thieves and liars. This was an honourable house [...] we were respected by everyone. [...] They are all screwed up [...] I know why they are. Disturbed [psychologically], did you say Colin was? They're all war children, that is why. Two terrible wars and this is the result. [...] Do you think there can be wars like that, terrible, terrible wars and then you can say, All right, that's over, now back to normal. Nothing's normal now. The children aren't normal. And you too [...] (137-138)

The delinquency and impoliteness of the third generation is in fact an echo of the chaos, the mad, and madness of the second generation. Colin's impoliteness to France is a mirror image of Johnny's impoliteness to Julia. Colin's state of being "disturbed" or having psychological problems is a mirror image of Phyllida. Thus the term "war children" could be extended to the second generation because Johnny, Frances, and Phyllida are also born after the war. The chaos of one generation duplicates itself in the other. Colin points this out clearly to his mother:

It's your generation [...] It's all of you [...] Saving the world. Paradise on every new agenda [...] Father saving the world, a few million dead here, a few million dead there [...] Who the bloody hell are you-world savers every one, and making deserts [...] Do you realise? We are all screwed up [...] $(221-222)$

Note how Colin's words reflect those of his mother's and grandmother's cited above. Unfortunately, Colin, who considers himself the sane among the insane, has to undergo psychiatric treatment. He points out that parents' fail in their parenting role because the role is displaced and geared towards a bigger picture- the world at large - which they want to save. Consequently, the absence of proper parenting by both parents turns the third generation into "screwed up" children infected with moral and psychical problems. Note also the use of opposite images painted by Colin as in "saving the world" and "making deserts" (devastation/death). This suggests that the dreamed Paradise ends as Wastelands. As such, the dreams of The Revolution mutates into nightmares.

\section{The Sixties in The Sweetest Dreams}

In her introduction to the novel, Lessing hopes to recapture the spirit of the contradictory era, the Sixties ${ }^{7}$. The killings during the wars develop into "Free Love" expressed by hippies, a philosophy with roots deep in human consciousness - a philosophy that needs a little encouragement to resurface. It manifests itself in the form of new knowledge about human sexuality: pills and psychedelic drugs and a counter-culture which rejected conservative ways and embraced individual freedom. In the novel, girls and boys sleep with each other openly and couples lie together in the grass in the meadow behind the school. In another instant a girl cuddles on a bed with a boy who had a room in the same corridor, leaving the door open but no one took any notice (166). The physical rubble of war now mutates into moral rubble displayed by a hippie and bohemian lifestyle. Drugs, pills such as amphetamines (19), alcohol, sexual freedom and abortion marred biblically-based morals. In France, every hero has a group of girls who serve and sleep with him (184). Even the first generation such as Julia, with their moral code and ethics, seems to approve of the sexual freedom movement as reflected in her remark to Collin that it is not healthy for a young man to have no sex life. Collin admits he has a dark dangerous secret life, full of mad romantic encounters (219), and at school he is said to have stolen his headmaster's love (52). This implies homosexual attraction between teacher/student. Homosexuality is also portrayed in Mary Constable and Phyllida's relationship as companions and lovers (251). The adults are involved in the cornucopia of activities of the upper class in the swampy beds and pungent grooves of Swinging London (159), Jasper's drugs and wild parties (263), and Frances' and Harold's weekend affair. Even the old Julia and Wilhelm have their own affair. Incest is observable in a step sister/brother (Sylvia/Andrew) couple who sleep together, but no comment or advice was given to either one of them.

On the political front, the chaos occurs in mass - both threatening and deadly and geared towards authority. Politically unpleasant events take place. Thousands of politicos participate in the street fighting, confront the police, throw stones, run battles, and build barricades (184). It is an era filled with demonstrations, riots, sit-ins, 
International Journal of Applied Linguistics \& English Literature

ISSN 2200-3592 (Print), ISSN 2200-3452 (Online)

Vol. 1 No. 3; July 2012 [Special Issue on World Literature in English]

lock-outs, and battles of all kinds (188). People literally lay their problems on the streets forming mass movement and displaying herd psyche where instinct dominates.

An interesting parallel could be seen between Colin and his psychiatrist and the herd and the streets. Colin pours out his problems to a silent and unresponsive psychiatrist. Similarly the streets become the silent and unresponsive "psychiatrist" where the crowd/herd throws their frustrations and problems. As a group/herd, people are highly charged with destructive energy, full of aggression and brutality, which are also dirty. They no longer adhere to the notion of cleanliness as next to Godliness and dirt and smelliness becomes as good as the party card (189). The unconscious contents not only create social chaos but they also contribute to the psychical chaos that leads to psychological disorders and insanity.

\section{Conclusion}

In the novel the "shred of reason" and morality that keep the "inflated consciousness" in check-and-balance comes from mothering and not from the 'heroic figures' such as Johnny, social/moral institutions (e.g., the Church) or psychiatrists. While Johnny pulls the third generation into the "inflated consciousness" Frances pulls them out of it, injecting reasons and conscience into the third generation through letters for the "Dear Aunt Vera column." She reads letters of concerned mothers at the dinner table to the third generation.

Frances' dinner table connects the third generation physically, psychically and morally. Her dining table becomes a place where the children lay the contents of their unconscious to be consciously discussed and injected with elements of conscience and morality. For example, Geoffrey's steeling habits. Though it is considered right by Johnny it is disproved by Frances and injected with elements of morality by Andrew who says it is a wrong and inferior deed (49-50). Johnny and Andrew represent the unconscious and conscious, respectively, but it is Frances who adjusts the right/wrong scale by drawing out letters to "Dear Aunt Vera" on parallel issues, reading them to the third generation.

Lessing's portrayal of the teenagers (the third generation) is believably true. She presents teenagers facing turmoil amidst the moral and psychical rubble of World War I and World War II, swayed between The Revolution's ideology, delinquent activities, voice of conscience/reason and morality. Teenage is an age of turmoil and moratorium identity, a period where role models and mothering roles are crucial. Lessing balances the effects of the negative parenting role provided by Johnny with Frances' mothering role. Apart from Frances, there are other mothers all over the world:

Thus did the house-mothers, the earth mothers, who proliferated everywhere in the Sixties slowly become aware of each other's presence out there, and understand that they were part of the phenomenon: the geist was at it again. They networked, before the term had become part of the language. They were a network of nurturers. Of neurotic nurturers. As 'the kids' had explained, Frances was working out some guilt or other [...] As for Sylvia, she had a different 'line' [...] that Frances was working on her karma, damaged in the previous life. (143)

Though she is not the conventional comfortable mother with a sort of "benevolent freak of nature" (142), who lives in a bohemian household (60), a house Rose terms as the "Hall of Freedom" (54), she plays her role well. She is a "benevolent freak" that reaches out to the "freaking kids' infected by an "inflated consciousness"- a disorder Frances was infected with but is now healed - injecting elements of reasons/conscience into them.

Other characters turn from the West turning to the East for a spiritual remedy by practising yoga, I-ching, Maharishi, Subud (126), and Buddhism (128), as displayed by Jack and his cronies (136), in an attempt to look for order amidst the chaotic Sixties. But the turn to the East is partial as represented in the healed Phyllida, who leads a normal and successful life as an independent physiotherapist known as Dr. Phyllida Lennox, mixing elements of the West and the East and Gypsies. The West is represented by the image of St Frances on the glass panel and Freud's inspired couch in her office, while the East and Gypsy elements are represented by an oriental rug on her floor and the multi-coloured kaftan, multiple beads, earrings and bracelets she wears (248-249).

Interestingly, Lessing places mothering as the main "shred of reason" that acts as leverage in mediating and uniting the unconscious contents that causes "inflated consciousness" among the third generation in Swinging London in the Sixties. An instance of her success is portrayed in the change in Geoffrey's life. He becomes a 
International Journal of Applied Linguistics \& English Literature

ISSN 2200-3592 (Print), ISSN 2200-3452 (Online)

Vol. 1 No. 3; July 2012 [Special Issue on World Literature in English]

"cool young man" who takes part in a Struggle for Civic Rights (142), a one hundred and eighty degree turn from the delinquent teenager he once was.

\section{Notes}

${ }^{1}$ Lessing, Doris. The Sweetest Dreams London: Harper Collins 2002

${ }^{2}$ A term originally used by Lessing in the novel. See Dreams, 54

${ }^{3}$ See CW 12:563/p.480 - 481 "Religious Ideas in Alchemy" pp. 225-484 on inflated consciousness, unconscious and herd instinct

${ }^{4}$ See CW7:30, Jung, C. G. "On the Psychology of the Unconscious: The Eros Theory". In Collected Works Vol.7: Two Essays on Analytical Psychology $2^{\text {nd }}$ ed. London: Routledge 1953/1990 reprint para 16-34

${ }^{5}$ See CW 10:448-454, Jung, C. G. "The Fight With the Shadow" In Collected Works Vol. 10 Civilisation in Transition. USA: Bollingen Foundation, 1964 para 444-457 [A Broadcast talk in the Third Programme of the British Broadcasting Corporation, on November 3, 1946]

${ }^{6}$ Erich Goode thinks that the most fascinating of all human phenomena is the world of deviance. He views deviance as having a dual feature whereby in these two realms the behaviour and its condemnation interact with each other. See Deviant Behaviour $5^{\text {th }}$ ed. New Jersey: Prentice Hall, 1997, viii

${ }^{7}$ See "Author's Note" to The Sweetest Dream and an internet article titled "A Trip through the Sixties: The Sexual Revolution" at http://www.hippy.com/php/article-223.html that describes the moral slide of the sixties

\section{References}

Lessing, Doris. The Sweetest Dreams. London: Harper Collins, 2002.

Jung, C. G. "On the Psychology of the Unconscious: The Eros Theory". In Collected Works Vol.7: Two Essays On Analytical Psychology, 2nd ed. London: Routledge. 1953/1990.

Jung, C. G. "The Fight With the Shadow" In Collected Works Vol. 10: Civilisation in Transition. New York: Bollingen Foundation, 1964 para 444-457 [A Broadcast talk in the Third Programme of the British Broadcasting Corporation, on November 3, 1946]

Erich Goode. Deviant Behaviour, 5th ed. New Jersey: Prentice Hall, 1997.

\section{Noor Azah Catherine Abdullah}

Noor Azah is currently doing her Phd in Universiti Putra Malaysia exploring the psychological contributions of stories in Arabian Nights. Her areas of interest include cultural studies, philosophy, and postcolonial literature.

\section{Rohimmi Noor}

Rohimmi is a lecturer at the Faculty of Modern Languages and Communication, Universiti Putra Malaysia. His research interest includes postcolonial literature, modernist writers, and literary criticism. 